\title{
Stereoselective, nitro-Mannich/lactamisation cascades for the direct synthesis of heavily decorated 5-nitropiperidin-2-ones and related heterocycles
}

\author{
Pavol Jakubec ${ }^{1}$, Dane M. Cockfield ${ }^{2}$, Madeleine Helliwell ${ }^{2}$, James Raftery ${ }^{2}$ \\ and Darren J. Dixon*1
}

\section{Full Research Paper}

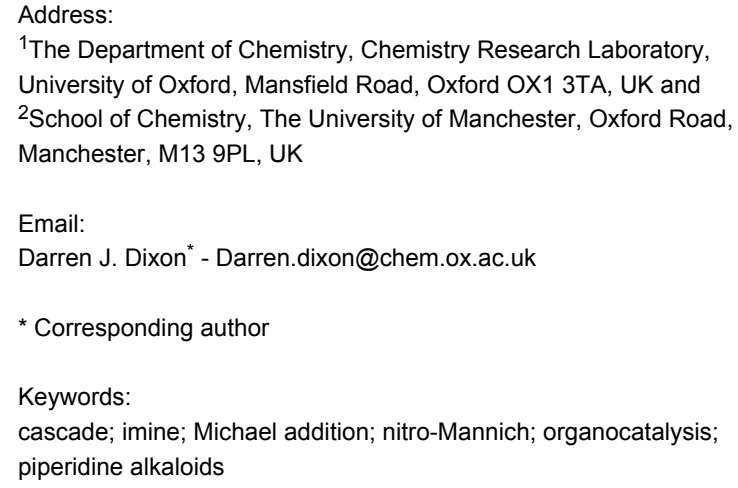

${ }^{1}$ The Department of Chemistry, Chemistry Research Laboratory, University of Oxford, Mansfield Road, Oxford OX1 3TA, UK and ${ }^{2}$ School of Chemistry, The University of Manchester, Oxford Road, Manchester, M13 9PL, UK

\section{Email:}

Darren J. Dixon* - Darren.dixon@chem.ox.ac.uk

* Corresponding author

Keywords:

cascade; imine; Michael addition; nitro-Mannich; organocatalysis; piperidine alkaloids

\begin{abstract}
A versatile nitro-Mannich/lactamisation cascade for the direct stereoselective synthesis of heavily decorated 5-nitropiperidin-2-ones and related heterocycles has been developed. A highly enantioenriched substituted 5-nitropiperidin-2-one was synthesised in a four component one-pot reaction combining an enantioselective organocatalytic Michael addition with the diastereoselective nitroMannich/lactamisation cascade. Protodenitration and chemoselective reductive manipulation of the heterocycles was used to install contiguous and fully substituted stereocentres in the synthesis of substituted piperidines.
\end{abstract}

\section{Introduction}

The piperidine ring is a common motif found in many biologically active natural products and drugs. The structures of these compounds range from the architecturally complex polycyclic ring systems, such as those found in the alkaloids haliclonacyclamine F [1], manzamine A [2-6], and reserpine $[7,8]$ (Figure 1), to relatively simple piperidines found in pharmaceutical compounds, such as paroxetine $[9,10]$ and alvimopan [11].

The abundance of this motif in desirable targets has led to considerable interest from the synthetic community [12-19]. Common synthetic approaches to incorporate this motif include nucleophilic additions to pyridine rings and further manipulation [20-25], intramolecular iminium ion cyclisation [26-29], reduction of unsaturated heterocycles [30-32], ring closure via intramolecular nucleophilic substitution [33-37], cascade reactions of enamines/imines and aldehydes [38-41], and ring- 


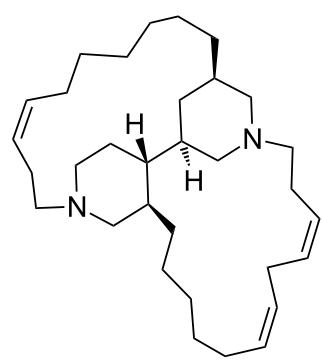

haliclonacyclamine $\mathrm{F}$

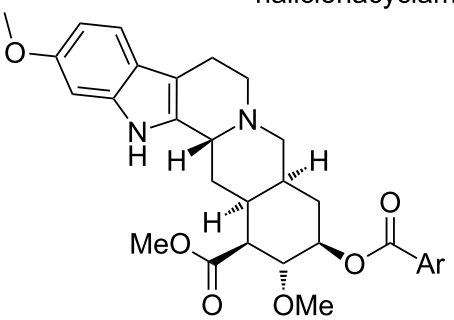

reserpine

$\operatorname{Ar}=3,4,5$-trimethoxyphenyl

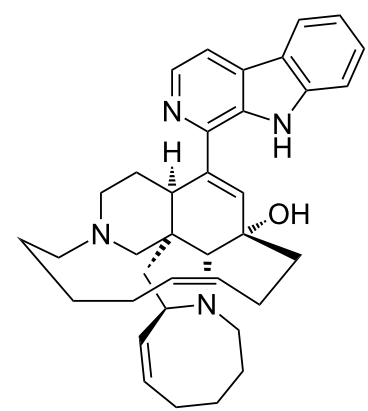

manzamine A<smiles>C[C@H]1CN(C[C@H](Cc2ccccc2)C(=O)NCC(=O)O)CC[C@]1(C)c1cccc(O)c1</smiles>

alvimopan

Figure 1: Biologically active natural products and drugs containing the piperidine ring.

closing metathesis followed by hydrogenation [42-48]. Arguably the most general route employs cycloadditions and subsequent manipulation of the partially unsaturated ring system [49-53]. We believed a powerful entry to piperidine rings and related heterocyclic structures could employ a nitroMannich/lactamisation cascade of $\gamma$-nitro ester starting materials with imines (cyclic or acyclic, preformed or formed in situ) as a key step. Not only could this approach allow the rapid generation of structural complexity, but the products would be amenable to further synthetic transformations. Furthermore, the $\gamma$-nitro ester starting materials are accessible in an enantioenriched form by using an organocatalytic Michael addition methodology, which was developed by our group and others [54-59].
In pursuit of this we have successfully harnessed the power of the nitro-Mannich/lactamisation cascade in a formal synthesis of $(3 S, 4 R)$-paroxetine [60], in the construction of architecturally complex polycyclic alkaloid structures [61] and more recently as a key complexity building step in the total synthesis of nakadomarin A [62-65]. Herein we wish to report our full findings in this synthetically powerful cyclisation cascade.

The first example of a simple nitro-Mannich/lactamisation cascade was reported independently by Mühlstädt and Jain in the mid-1970s $[66,67]$. The condensation of methyl 4-nitrobutanoate 6 (Scheme 1; $\mathrm{R}^{2}=\mathrm{R}^{3}=\mathrm{R}^{4}=\mathrm{H}$ ) with aromatic aldehydes $3\left(\mathrm{R}^{5}=\mathrm{Ar}\right)$ and ammonium acetate provided access

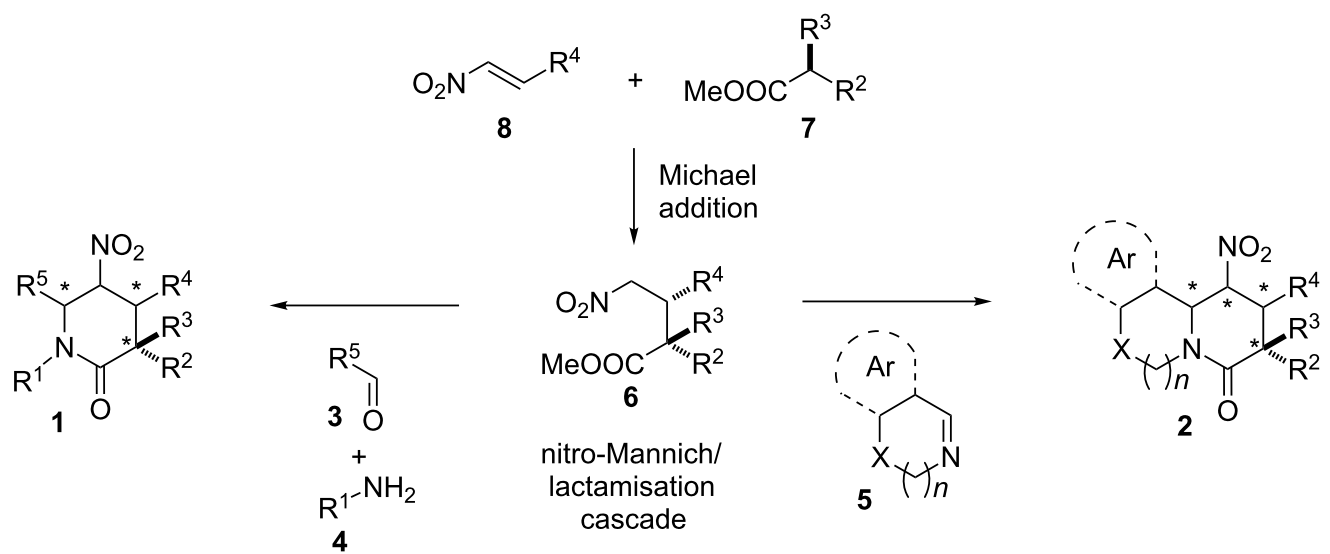


to simple 6-aryl-substituted 5-nitropiperidin-2-ones $\mathbf{1}\left(\mathrm{R}^{1}=\right.$ $\mathrm{R}^{2}=\mathrm{R}^{3}=\mathrm{R}^{4}=\mathrm{H}, \mathrm{R}^{5}=\mathrm{Ar}$ ). The power of this transformation was not immediately recognised and only in the last two decades has the cascade been successfully applied to the synthesis of simple biologically active compounds and their precursors, such as $( \pm$-CP-99,994 [68,69], inhibitors of farnesyltransferase [70,71], selective dipeptidyl peptidase IV inhibitors [72,73], and functionalised bispidines [74]. Very recently, a related cascade inspired by the original work of Jain incorporating $\mathrm{C}-\mathrm{C}$ bond formation was accomplished through a nitroMannich reaction [75-80] of nitro carbonyl compounds with imines, followed by ring-closure condensation [81-83]. Despite improvements of, and developments to, the nitro-Mannich/lactamisation cascade during the last few decades, we recognised, that further enhancement of the method was necessary to transform it into a general synthetic tool of use in both medicinal chemistry and natural-product synthesis.

\section{Results and Discussion}

To allow us to further explore the nitro-Mannich/lactamisation cascade, a range of Michael adducts $\mathbf{6 a - e}$ were synthesised on a gram scale by the reaction of active methylene or methine carbon acids with nitro olefins in the presence of DABCO (20-30 mol \%) in THF (Scheme 2). Where diastereoisomers were created in the Michael addition step and stereocontrol was poor, the diastereomeric mixtures were recrystallised to afford single diastereomers $\mathbf{6 a}, \mathbf{b}, \mathbf{e}$. The relative stereochemistry of the major diastereomer $\mathbf{6 e}$ was assigned unambiguously by single-crystal X-ray analysis.
With a range of suitable test substrates in hand, formaldehydederived imines were then investigated in the nitro-Mannich/lactamisation reaction. Aqueous formaldehyde (3a) and allylamine (4a) were added to a methanol solution of lactam $6 \mathbf{a}$ and the mixture heated under reflux for 4 hours until judged to be complete by TLC. Pleasingly, the desired $\delta$-lactam product 1a was isolated in $90 \%$ yield as a single diasteromer (Scheme 3) [84]. Under identical reaction conditions the other Michael adducts, lactone $\mathbf{6 b}$ and ester $\mathbf{6 c}$, provided moderate yields of the desired $\delta$-lactams $\mathbf{1 b}$ and $\mathbf{1 c}$ as single diastereoisomers in both cases. The diastereoselectivity in the latter case is notable, as the quaternary stereogenic centre is created in the lactamisation step. The relative stereochemical configurations of $\mathbf{1 a - c}$ were established by ${ }^{1} \mathrm{H}$ NMR spectroscopic analysis. For more details on the elucidation of the relative configuration see [61] and Supporting Information File 1. To incorporate substituents at the 6 position of the piperidine ring in $\mathbf{1}$, imines derived from aldehydes other than formaldehyde were required in the reaction. Thus acetaldehyde (3b), anisaldehyde (3c) and glyoxylic acid (3d) were chosen as representative aliphatic, aromatic and functionalised aldehydes, respectively, and reacted with Michael adducts 6a and $\mathbf{6 d}$ under the conditions described above with allylamine. High diastereoselectivities were observed in each case and the reaction products $1 \mathbf{d}-\mathbf{g}$ were obtained in moderate to good yields $(50-74 \%)$. The relative stereochemistry of $\mathbf{1 g}$ was assigned unambiguously by singlecrystal X-ray analysis. Similarly, variation at position 1 required the use of an alternative amine for in situ imine formation. Thus replacement of allylamine (4a) with benzylamine (4b) in the

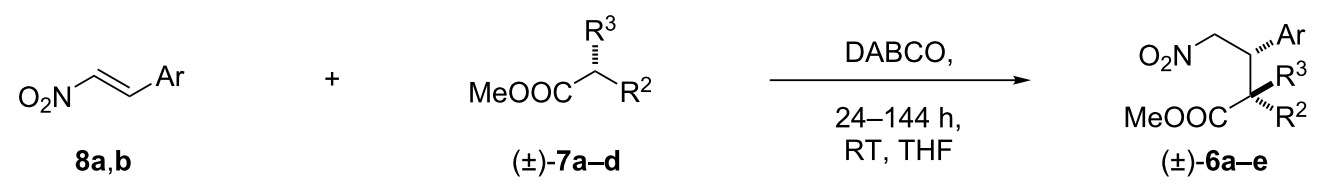<smiles></smiles>

(士)-6a, 90\%, dr 67:33 (recrystallised to $>98: 2$ )<smiles>COC(=O)C(C(=O)OC)[C@@H](C[N+](=O)[O-])c1ccccc1</smiles>

$( \pm)-6 d, 86 \%$<smiles>COC(=O)[C@@]1(C(=O)O[N+](=O)[O-])OCC[C@H]1c1ccccc1</smiles>

( \pm )-6b, 88\%, dr 65:35 (recrystallised to $>98: 2$ )<smiles>COC(=O)C1(C(=O)O[Na])CCN(C)C1=O</smiles>

$( \pm)-6 e, 55 \%$, dr $62: 38$ (recrystallised to $>98: 2$ )

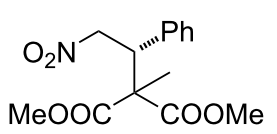

$( \pm)-6 c, 70 \%$

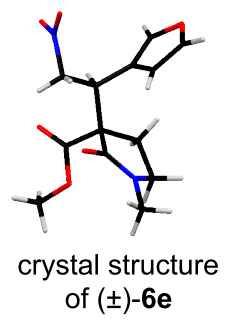




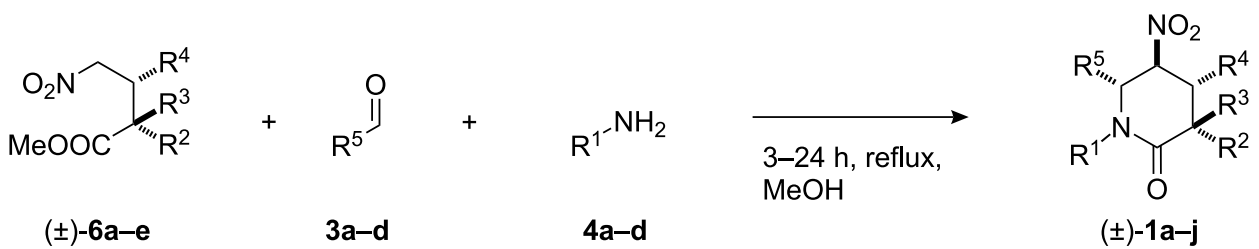

$( \pm)-6 a-e$

3a-d<smiles></smiles>

$( \pm)-1 \mathrm{~b} 52 \%$<smiles>C=CCN1CC([N+](=O)[O-])[C@H](c2ccccc2)[C@](C)(C(=O)OC)C1=O</smiles>

( \pm$)-1$ a $90 \%$<smiles>C=CCN1C(=O)C(C(=O)OC)[C@H](c2ccccc2)[C@H]([N+](=O)[O-])[C@@H]1C</smiles>

$( \pm)-1 d$ 61\%<smiles>C=CCN1C(=O)[C@]23CCN(C)C(=O)[C@@]2(c2ccccc2)C([N+](=O)[O-])[C@@H](C)N1C3</smiles>

$( \pm)-1$ e $67 \%$<smiles>C=CCN1C(=O)[C@]2(CCN(C)C2=O)[C@H](c2ccccc2)C([N+]#N)[C@H]1[N+](=O)[O-]</smiles>

( \pm )-1f $50 \%$

reaction time $20 \mathrm{~d}$<smiles>CCCCN1CC([N+](=O)[O-])[C@@H]2[C@@H]3C(=O)N(C)CC[C@@]3(C1=O)[C@H]2c1ccoc1</smiles>

(士)-1i $82 \%$<smiles>C=CCN1CN2C(C(=O)O)C([N+](=O)[O-])[C@@]3(Pc4ccccc4)C(=O)N(C)CC[C@]23C1=O</smiles>

$( \pm)-1 \mathrm{~g} 74 \%$ water used as solvent<smiles>CC#CCCN1CC([N+](=O)[O-])[C@H]2c3ccoc3C[C@@]2(C(=O)N(C)C)C1</smiles>

$( \pm)-1 \mathrm{j} 75 \%$

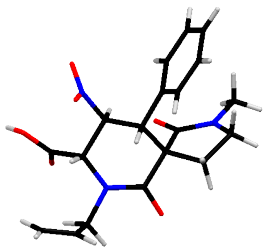

crystal structure of $( \pm)-\mathbf{1 g}$<smiles></smiles>

$( \pm)-1 \mathrm{~h} 81 \%$

water used as cosolvent

Scheme 3: Nitro-Mannich/lactamisation cascade with in situ formed imines.

reaction afforded the desired product $\mathbf{1 h}$ in good yield and as a single diastereoisomer (Scheme 3).

The use of substrate 6e allowed us to investigate further variations at positions 1 and 4; piperidin-2-ones $\mathbf{1 i}$ and $\mathbf{1} \mathbf{j}$ were formed as single diastereoisomers in good yields $(82 \%$ and $75 \%$ ) when nitro-Mannich/lactamisation cascades were carried out with formaldehyde (3a) and butylamine (4c) or hept-5-yn-1amine (4d), respectively. To extend the cascade methodology to the potential construction of architecturally complex piperidinering-containing polycyclic natural products, the successful employment of preformed cyclic imines was required.

Accordingly, the imine 5a (Figure 2) was synthesised from commercially available 2-phenylethylamine [85] and reacted with the chromatographically inseparable mixture of diastereo-<smiles>C1=NCCc2ccccc21</smiles>

$5 a$<smiles>C1=NCCc2c1[nH]c1ccccc21</smiles>

5d<smiles>O=[N+]([O-])c1ccc2c(c1)C=NCC2</smiles>

$5 \mathrm{~g}$

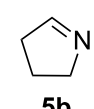

$5 b$<smiles>COc1cc2c(cc1OC)CCN=C2</smiles>

$5 e$<smiles>C1=NCCCc2ccccc21</smiles>

$5 \mathrm{~h}$<smiles>C1=NCCCC1</smiles>

$5 c$<smiles>C1=NCC(c2ccccc2)c2ccccc21</smiles><smiles>C1=NCCOc2ccccc21</smiles>

Figure 2: Cyclic imines employed in nitro-Mannich/lactamisation cascade. 
<smiles>COC(=O)C1(CN=O)C(=O)N(C)CC1c1ccccc1</smiles>

$( \pm)-6 \mathbf{a}$<smiles>COC(=O)C1(CN=O)C(=O)N(C)CC1(CO)c1ccccc1</smiles>

$( \pm)-6 a "$

dr 6a:6a" = 38:62

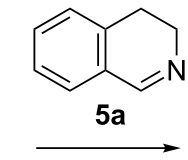

$\mathrm{H}_{2} \mathrm{O}, 70{ }^{\circ} \mathrm{C}, 48 \mathrm{~h}$ combined yield $72 \%$<smiles>CN1CCC2(C(=O)C1=O)C(=O)N1CCc3ccccc3C1C2[N+](=O)[O-]</smiles>

$( \pm)-2 a, 28 \%$<smiles>CN1CCC2(C(=O)C1=O)C(=O)N1CCc3ccccc3C1C2[N+](=O)[O-]</smiles>

(士)-2a", 42\%

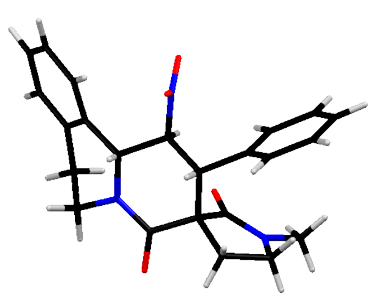

crystal structure of $( \pm)-\mathbf{2 a}$

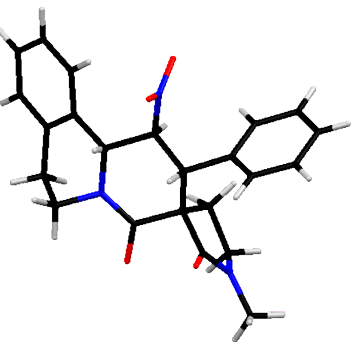

crystal structure of ( \pm )-2a"

Scheme 4: Nitro-Mannich/lactamisation cascade of diastereomeric Michael adducts $6 \mathbf{a}, \mathbf{6 a}$ " with cyclic imine $5 \mathbf{a}$

meric Michael adducts $\mathbf{6 a}$ and $\mathbf{6 a}$ ", under slightly modified conditions (water was used instead of $\mathrm{MeOH}$ as the solvent). Pleasingly the reaction proceeded smoothly and only two, 2a and 2a", of the possible eight diastereoisomeric tetracyclic compounds were obtained in good combined yield $(70 \%$, Scheme 4). Chromatographic separation followed by singlecrystal X-ray diffraction studies of both isomers allowed unambiguous determination of the relative stereochemical configurations in each case. For more details of the elucidation of the relative configuration see Supporting Information File 1. The products were epimeric only at the quaternary centre and therefore both new stereogenic centres were created with high stereocontrol in each case.

Imines 5a-5i [61,86-94], chosen so as to afford common target motifs in the products [95-102], were synthesised and reacted with diastereomerically pure Michael adduct $\mathbf{6 a}$ and Michael adduct $\mathbf{6 d}$ following the conditions described above. Employing the optimal reaction conditions, products $\mathbf{2 a}-\mathbf{2 l}$, which possess 4,5-trans relative stereochemistry, were formed in moderate to good yields and with high diastereoselectivities as described in our previous work (Scheme 5) [61].

Interestingly, however, when diastereomerically pure Michael adduct $\mathbf{6 d}$ was reacted with imine $\mathbf{5 e}$, the nitropiperidinone $\mathbf{2 m}$, possessing 4,5-cis relative stereochemistry [103], was isolated in $70 \%$ yield as a single diastereomer (Scheme 5). This one exceptional case together with the generally high diastereocontrol in the formation of piperidinones $\mathbf{1} \mathbf{a}-\mathbf{j}$ and $\mathbf{2} \mathbf{a}-\mathbf{l}$ is interesting and worthy of further commentary. With the knowledge that the retro-Michael reaction does not occur under standard reaction conditions (Scheme 4) and assuming that the final step of the cascade (the $\delta$-lactam ring formation) is irreversible, there are at least three possible explanations for the high diastereocontrol in the formation of $\mathbf{1 a}-\mathbf{j}$ and $\mathbf{2} \mathbf{a}-\mathbf{I}$ :

- The first is that the nitro-Mannich step is highly diastereoselective and lactamisation occurs subsequently without any effect on the stereochemical outcome of the cascade.

- The second is that the nitro-Mannich reaction [78-80] is fast and reversible (but not necessarily stereoselective), and only one of the diastereomeric nitro-Mannich products preferentially cyclises in the irreversible lactamisation step to the (likely) most thermodynamically stable product (Scheme 6, Path A).

- The third is similar to the second, but the two direct nitroMannich products A and B with the observed configurations at the 6 position preferentially lactamise, and there is a postcyclisation epimerisation at the stereogenic carbon bearing the nitro group allowing equilibration to the (likely) most thermodynamically stable product (thermodynamic control, Path B) or a crystallisation-induced diastereoselectivity to give products $\mathbf{2}$ or 2' with the nitro group occupying an axial or equatorial position, respectively [104-108] (Scheme 6, Path B/B').

A further scrutiny of each hypothesis was, unfortunately, hampered by our failure to isolate or identify in situ the direct nitro-Mannich products from the reaction mixtures or to prepare them separately using standard procedures for a nitro-Mannich 


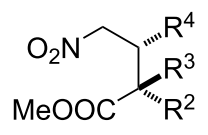

$( \pm)-6 a$ or $( \pm)-6 d$

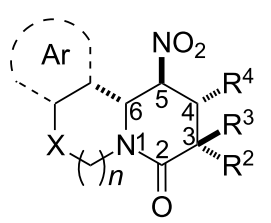

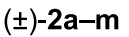<smiles>CN1CC[C@@]2(C(=O)C1=O)C(=O)N1CCc3ccccc3[C@H]1C([N+](=O)[O-])C2c1ccccc1</smiles>

(土)-2a, 76\%, dr 98:2 (97:3)<smiles>CN1CC[C@]23C(=O)N(CCc4ccc([N+](=O)[O-])cc4[C@@H]12)C(=O)[C@H](c1ccccc1)[C@H]3[N+](=O)[O-]</smiles>

( \pm )-2e, $73 \%{ }^{\text {b }}$ $\mathrm{dr}>99: 1(>99: 1)^{\mathrm{a}}$<smiles>CC(=O)C1C(=O)N2CCc3ccccc3[C@H]2C([N+](=O)[O-])[C@@H]1c1ccccc1</smiles>

$( \pm)-2 \mathbf{i}, 75 \%$, dr 98:2 (98:2)<smiles>CC(=O)C1C(=O)N2CCCC[C@H]2C([N+](=O)[O-])[C@@H]1c1ccccc1</smiles>

(士)-2b, 58\%, dr 98:2 (97:3)<smiles>CCN1C(=O)[C@@H]2CCN(C)[C@@H](c3cc(OC)c(OC)cc31)C([N+](=O)[O-])[C@H]2c1ccccc1</smiles>

( \pm )-2f, $74 \%^{\mathrm{b}}$, dr 94:6 (95:5)<smiles>CN1CC[C@]23C(=O)N4CCC[C@H]4C([N+](=O)[O-])[C@@H]2C(=O)N3C1</smiles>

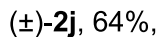
$\operatorname{dr} 66: 34(66: 34)^{\mathrm{a}}$<smiles>CN1CC[C@@]23CN1C(=O)[C@@H]2[C@@H]1c2[nH]c4ccccc4c2CCN(C3=O)[C@@H]1[N+](=O)[O-]</smiles>

(士)-2c, $91 \%$, $\mathrm{dr}>99: 1(>99: 1)^{\mathrm{a}}$<smiles>CC(=O)C1C(=O)N2CCOc3ccccc3[C@H]2C(c2ccccc2)[C@H]1[N+](=O)[O-]</smiles>

$( \pm)-2 \mathrm{~g}, 71 \%$, $\mathrm{dr}>99: 1(>99: 1)^{\mathrm{a}}$<smiles>CN1CC[C@]23C(=O)N(C[C@H]2c2ccccc2)C(=O)[C@@H]([N+](=O)[O-])[C@@H]3c2ccccc2C1c1ccccc1</smiles>

$( \pm)-2 k, 85 \%$, dr 85:15 (85:15) $)^{a}$<smiles>COC(=O)C1C(=O)N2CCc3c([nH]c4ccccc34)[C@@H]2[C@H](c2ccccc2)[C@H]1[N+](=O)[O-]</smiles>

$( \pm)-2 d, 73 \%$, dr 97:3 (94:6)<smiles>CN1CC[C@]2(C(=O)C1=O)C(=O)N1CCCc3ccccc3[C@H]1C2[N+](=O)[O-]</smiles>

( \pm )-2h, $60 \%^{\mathrm{b}}$, $d r>99: 1(>99: 1)^{a}$<smiles>COC(=O)C1C(=O)N2CCCc3ccccc3[C@H]2C(c2ccccc2)[C@H]1[N+](=O)[O-]</smiles>

(士)-2I, 63\%, $\mathrm{dr}>99: 1(98: 2)^{\mathrm{a}}$<smiles>COC(=O)C1C(=O)N2CCc3cc(OC)c(OC)cc3[C@@H]([C@H]1C(C)=O)[C@H](c1ccccc1)[C@@H]2O</smiles>

( \pm )-2m', 70\%, , , c dr 98:2 (96:4)

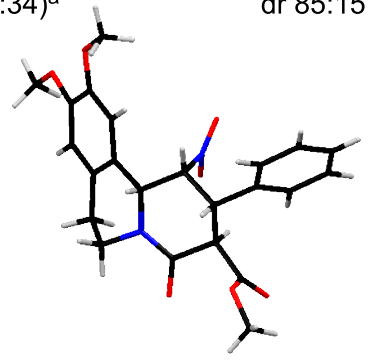

crystal structure of $( \pm)-2 m^{\prime}$

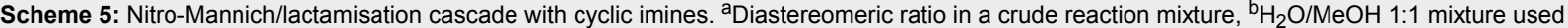
as a solvent, ${ }^{c}$ minor diastereomer $\mathbf{2 m}$ isolated in $5 \%$ yield.

reaction with imines [109]. The first hypothesis, however, was not supported by the low diastereoselectivity in the formation of $\mathbf{2 j}$, in which presumably the relatively fast irreversible cyclisation outcompetes the equilibration processes. Considering the relatively broad range of imines and Michael adducts involved in the stereoselective cascade, we believe that the second or third explanations are the most plausible and that the observed diastereoselectivities in the formation of products $\mathbf{1 a}-\mathbf{j}, \mathbf{2} \mathbf{a}-\mathbf{l}$ can be explained by following either Path A or B (Scheme 6).
The formation of product $\mathbf{2} \mathbf{m}$ ' with its exceptional 4,5-cis relative stereochemistry, can be explained by following path B' (Scheme 6). In this case the observed diastereoselectivity is believed to be driven by preferential crystallisation of the 4,5cis-configured diastereoisomer in the reaction flask rather than thermodynamic equilibration. As such, this reaction represents an example of a crystallisation-induced diastereomeric transformation (CIDT) [104-108]. This is supported by the observation that $\mathbf{2} \mathbf{m}$ and $\mathbf{2 m}$ ', when exposed separately to simulated 

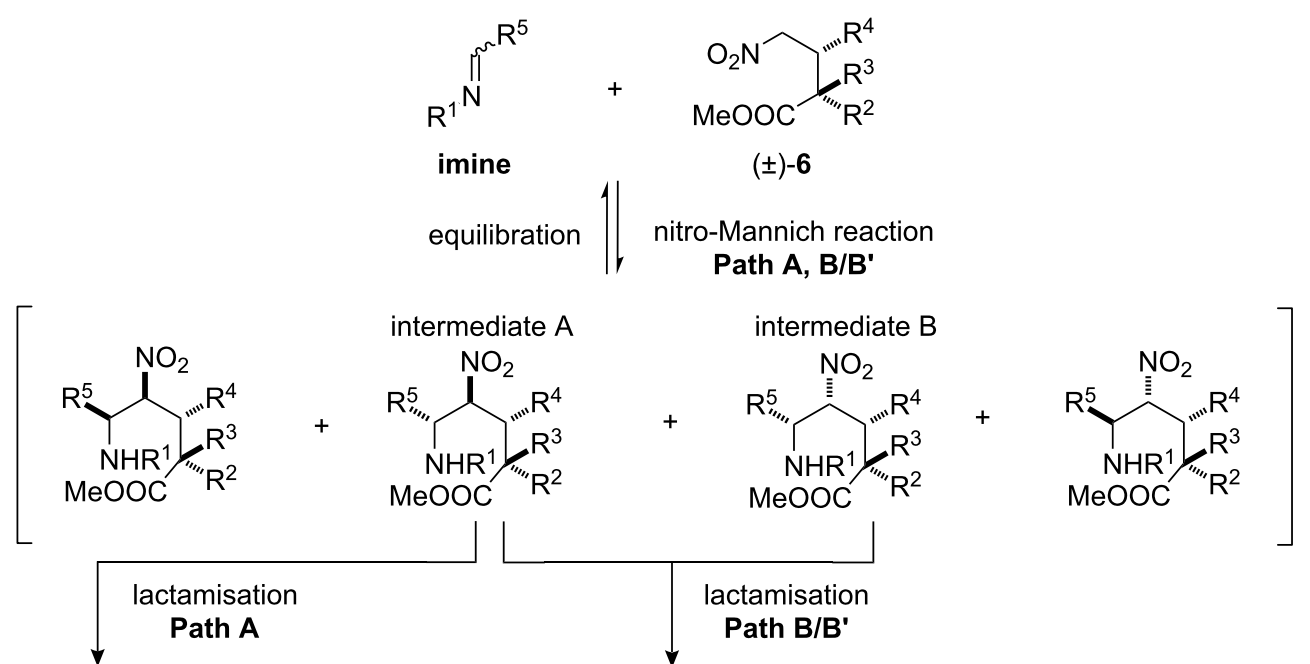<smiles>[R]C1[C@H]([N+]([2H])=O)[C@@H]([R])C([R])([R])C(=O)N1[R]</smiles>
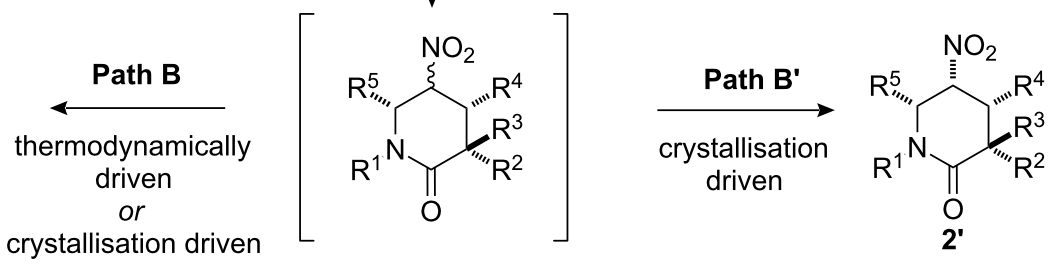

proposed transition state for the lactamisation step (Path A)
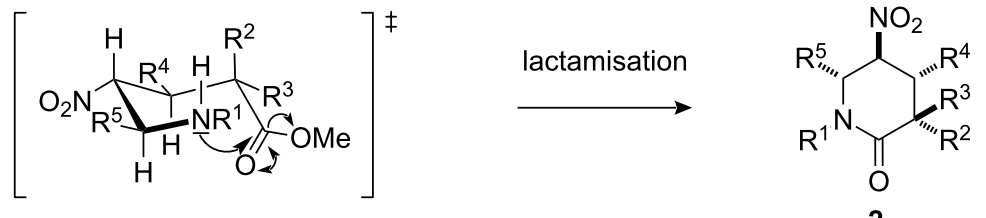

Scheme 6: Possible explanations for the observed high stereoselectivities in the nitro-Mannich/lactamisation cascade.

reaction conditions, epimerised at $\mathrm{C} 5$ to afford an identical 63:37 thermodynamic mixture of $\mathbf{2} \mathbf{m} / \mathbf{2} \mathbf{m}$ '(Scheme 7; Figure 3) [110].

With all of the necessary variations to the nitro-Mannich/lactamisation cascade having been tested, optimised and scoped, we looked at the possibility of combining it with a catalytic asymmetric synthesis of a particular Michael adduct, so as to construct a one-pot enantio- and diastereoselective fourcomponent coupling reaction (Scheme 8).

As described in our previous communication [61], the employment of bifunctional catalyst 9 [54,55] in a highly stereoselective two-stage one-pot cascade led to the formation of enan-<smiles>COC(=O)C1C(=O)N2CCc3cc(Cl)ccc3[C@H](C2c2ccccc2)C1[N+](=O)[O-]</smiles>

$( \pm)-2 m^{\prime}:( \pm)-2 m$ 63:37<smiles>COc1cc2c(cc1OC)[C@@H]1C([N+](=O)[O-])[C@H](c3ccccc3)C(C(C)=O)C(=O)N1CC2</smiles>

$( \pm)-2 m 98: 2$ 


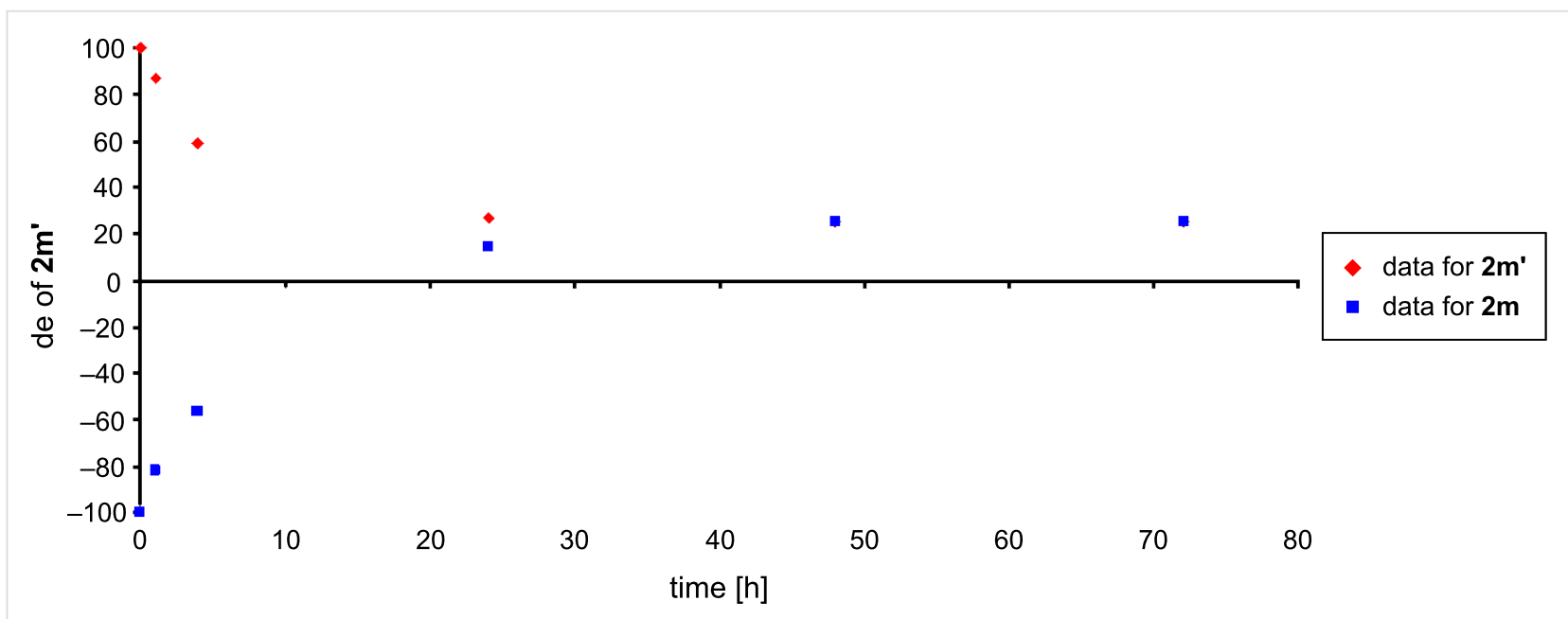

Figure 3: Thermodynamically driven epimerisation of 5-nitropiperidin-2-ones $\mathbf{2 m}$ and $\mathbf{2} \mathbf{m}$; identical diastereomeric excess measured for both diastereomers after $48 \mathrm{~h}$ and $72 \mathrm{~h}$.

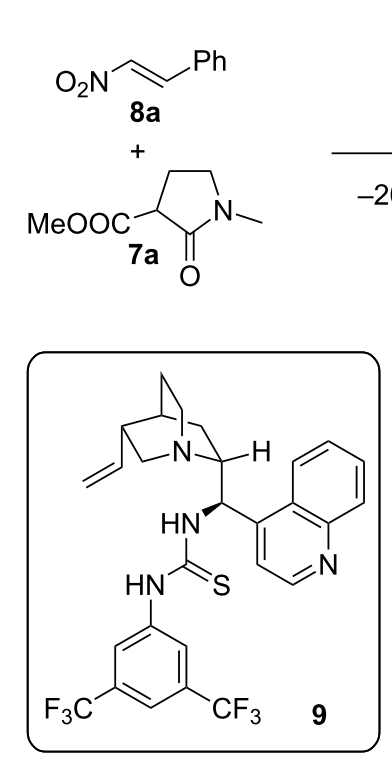

9

$20{ }^{\circ} \mathrm{C}, \mathrm{THF}$

$\left[\begin{array}{c}6 \mathbf{6} \\ {[}\end{array}\right]$

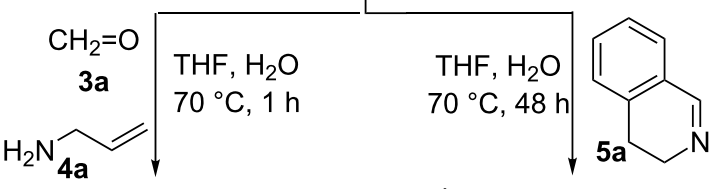<smiles>C=CCN1C[C@H]([N+](=O)[O-])C2(c3ccccc3)CN(C)C(=O)C2C1=O</smiles>

$(+)-1 a, 67 \%, 92 \%$ ee<smiles>CN1CC[C@@]2(c3ccccc3)[C@H]1C(=O)N1CCc3ccccc3C1[C@H]2[N+](=O)[O-]</smiles>

$(+)-2 a, 62 \%, 90 \%$ ee

Scheme 8: One-pot three/four-component enantioselective Michael addition/nitro-Mannich/lactamisation cascade.

tiomerically highly enriched spirocycle $(+)-\mathbf{1 a}($ Scheme 8$)$. In a repeat of the process but with the intention of targeting a piperidin-2-one ring-containing polycyclic scaffold, cyclic imine 5a was added at the second stage. Tetracyclic spirolactam 2a was isolated in high enantiomeric purity (90\% ee) in good chemical yield $(62 \%$, Scheme 8$)$ [111,112].

For the products of the nitro-Mannich/lactamisation cascade to be of use in alkaloid natural-product synthesis (or even simple stereoselective piperidine synthesis), controlled, reductive manipulation of both the nitro group and the lactam carbonyl were required. Although Nef-type oxidation followed by exhaustive reduction of the resulting carbonyl group was considered, Ono's radical procedure [113-116] was initially investigated. With some modification and optimisation, this was found to be compatible with the piperidin-2-one scaffold. Thus treatment of $\mathbf{2 a}$ and $\mathbf{2 c}$ with tributyltin hydride and AIBN in toluene under reflux smoothly afforded the protodenitrated products 10c and 10d in good yield (average 76\% yield, Scheme 9). Other examples of successful nitro-group removal were also achieved when substrates $\mathbf{1 i}$ and $\mathbf{1} \mathbf{j}$, lacking additional rings but bearing sensitive moieties (triple bond and furan 
<smiles>[R]C1C([N+](=O)[O-])C([Al])C2(CCN(C)C2=O)C(=O)N1[R]</smiles>

$( \pm)-1 \mathrm{i}, 1 \mathrm{j}, 2 \mathrm{a}, 2 \mathrm{c}$

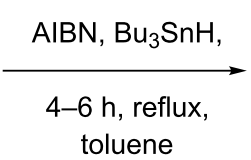

toluene<smiles>[R1]C1CC([Al])[C@]2(CCN(C)C2=O)C(=O)N1[R]</smiles>

$( \pm)-10 a-d$<smiles>CCCCN1CC[C@H](c2ccoc2)[C@@]2(C1)CN(C)C(=O)[C@H]2C</smiles>

$( \pm)-10 a, 53 \%$<smiles>CN1CC[C@@]2(C1=O)C(=O)N1CCc3ccccc3[C@H]1CC2c1ccccc1</smiles>

$( \pm)-10 c, 71 \%$<smiles>CC#CCCN1CC[C@H]2c3ccoc3C[C@@]2(C(=O)N(C)C)C(=O)N1C</smiles>

(士)-10b, $84 \%$<smiles>CN1CC[C@]2(c3ccccc3)C(=O)N3CCc4c([nH]c5ccccc45)[C@H]3C[C@@H]12</smiles>

$( \pm)-10 d, 81 \%$

Scheme 9: Protodenitration of 5-nitropiperidin-2-ones.

moiety), were exposed to identical reaction conditions. The piperidin-2-ones 10a and 10b were obtained in 53\% and $84 \%$, respectively. The reduction of both piperidin-2-one and pyrrolidin-2-one heterocycles to piperidine or pyrrolidine rings by using a range of reagents is well-documented in the literature $[117,118]$. However, we believed that a controlled,

chemoselective reduction would offer more options in any synthesis, and thus several commercially available reducing agents were screened in order to achieve selective reduction of only one lactam carbonyl. A notable find was that, by short exposure of denitrated heterocycle 10a-c to $\mathrm{LiAlH}_{4}$ in THF followed by quenching and treatment with $\mathrm{HCOOH}$, spirocycles 11a-c were obtained in good yields. The chemoselectivity of the reduction was unambiguously confirmed by single-crystal X-ray diffraction studies of 11c. Furthermore, the use of an excess of DIBAL at room temperature smoothly afforded the diamines 12a and 12b (Scheme 10).

\section{Conclusion}

In summary, a versatile nitro-Mannich/lactamisation cascade for the direct synthesis of heavily decorated 5-nitropiperidin-2ones and related heterocycles has been developed. A highly enantioenriched substituted 5-nitropiperidin-2-one was synthesised in a four-component one-pot cascade combining an enantioselective Michael addition with the diastereoselective nitro-Mannich/lactamisation cascade. Protodenitration and chemoselective reductive manipulation of the heterocycles could be used to install contiguous and fully substituted stereocentres in the synthesis of architecturally complex multicyclic alkaloid structures. The first applications of the developed methodology were disclosed recently as the total syntheses of paroxetine [60] and nakadomarin A [61-65] were successfully finished by employing the strategy as a fundamental synthetic tool. Further development is ongoing in our laboratory and the results will be disclosed in due course.

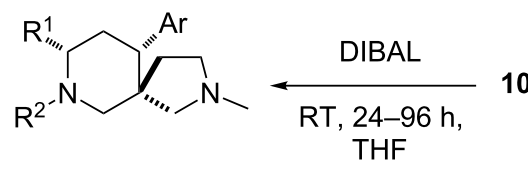

$( \pm)-12 a, b$

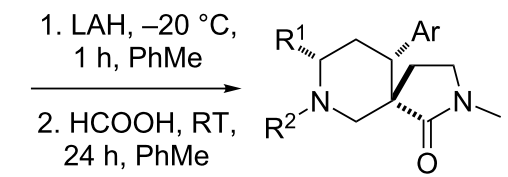

$( \pm)-11 a-c$<smiles>CN1CC[C@@]2(c3ccccc3)CCc3c([nH]c4ccccc34)[C@@H](C2)N2CCCCC12</smiles><smiles>CCCCN1CC[C@H](c2ccoc2)[C@@]2(CC(=O)N(C)C2)C1</smiles>

$( \pm)-11 a, 81 \%$<smiles>CC#CCCN1CC[C@@H](c2ccoc2)[C@@]2(C1)CN(C)C(=O)N2C</smiles>

$( \pm)-11 b, 77 \%$

$( \pm)-12 a, 71 \%$<smiles>CCCCN1CC[C@H](c2ccoc2)C2(CN(C)C2)C1</smiles>

$( \pm)-12 b, 75 \%$<smiles>CN1CC[C@]2(c3ccccc3)C[C@H]3c4ccccc4CCN3C[C@@H]12</smiles>

$( \pm)-11 c, 71 \%$

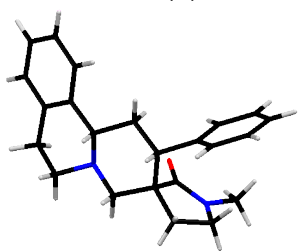

crystal structure of $( \pm)-11 \mathrm{c}$ 


\section{Supporting Information}

\section{Supporting Information File 1}

General experimental, copies of ${ }^{1} \mathrm{H}$ and ${ }^{13} \mathrm{C}$ NMR spectra for all new compounds (1a-j, 2a, 2a", 2m, 2m', 6b-e, 10a-d, 11a-c, 12a,b).

[http://www.beilstein-journals.org/bjoc/content/ supplementary/1860-5397-8-64-S1.pdf]

\section{Supporting Information File 2}

X-ray crystal structure of compound $\mathbf{2 m}$ '.

[http://www.beilstein-journals.org/bjoc/content/

supplementary/1860-5397-8-64-S2.cif]

\section{Supporting Information File 3}

X-ray crystal structures of compounds 1g, 2, 2a', 6e and

$11 \mathrm{c}$.

[http://www.beilstein-journals.org/bjoc/content/

supplementary/1860-5397-8-64-S3.cif]

\section{Acknowledgements}

We gratefully acknowledge Merck, Sharp and Dohme (Hoddesdon, U.K.) for a studentship (to D.M.C.); the EPSRC for a studentship (to D.M.C), a postdoctoral fellowship (to P.J.), and a Leadership Fellowship (to D.J.D.). We thank Dr Edward Cleator of MSD for useful discussion, Andrew Kyle and Katherine Bogle for X-ray structure determination and the Oxford Chemical Crystallography Service for use of the instrumentation.

\section{References}

1. de Oliveira, J. H. H. L.; Nascimento, A. M.; Kossuga, M. H.; Cavalcanti, B. C.; Pessoa, C. O.; Moraes, M. O.; Macedo, M. L.; Ferreira, A. G.; Hajdu, E.; Pinheiro, U. S.; Berlinck, R. G. S. J. Nat. Prod. 2007, 70, 538-543. doi:10.1021/np060450q

2. Magnier, E.; Langlois, Y. Tetrahedron 1998, 54, 6201-6258. doi:10.1016/S0040-4020(98)00357-3

See for a review on the isolation and the biological properties of manzamine $\mathrm{A}$.

3. Winkler, J. D.; Axten, J. M. J. Am. Chem. Soc. 1998, 120, 6425-6426. doi:10.1021/ja981303k

4. Humphrey, J. M.; Liao, Y.; Ali, A.; Rein, T.; Wong, Y.-L.; Chen, H.-J.; Courtney, A. K.; Martin, S. F. J. Am. Chem. Soc. 2002, 124, 8584-8592. doi:10.1021/ja0202964

5. Toma, T.; Kita, Y.; Fukuyama, T. J. Am. Chem. Soc. 2010, 132, 10233-10235. doi:10.1021/ja103721s

6. Yamada, M.; Takahashi, Y.; Kubota, T.; Fromont, J.; Ishiyama, A.; Otoguro, K.; Yamada, H.; Ōmura, S.; Kobayashi, J.-i. Tetrahedron 2009, 65, 2313-2317. doi:10.1016/j.tet.2009.01.032

7. Chen, F.-E.; Huang, J. Chem. Rev. 2005, 105, 4671-4706. doi:10.1021/cr050521a
8. Woodward, R. B.; Bader, F. E.; Bickel, H.; Frey, A. J.; Kierstead, R. W. Tetrahedron 1958, 2, 1-57. doi:10.1016/0040-4020(58)88022-9

9. Barnes, R. D.; Wodd-Kaczmar, M. W.; Curzons, A. D.; Lynch, I.; Richardson, J. E.; Buxton, P. C. Anti-depressant crystalline paroxetine hydrochloride hemihydrate. U.S. Patent 4,721,723, Oct 23, 1986.

10. Yu, M. S.; Lantos, I.; Peng, Z.-Q.; Yu, J.; Cacchio, T. Tetrahedron Lett. 2000, 41, 5647-5651. doi:10.1016/S0040-4039(00)00942-4

11. Furkert, D. P.; Husbands, S. M. Org. Lett. 2007, 9, 3769-3771. doi:10.1021/ol0713988

12. Bates, R. W.; Sa-Ei, K. Tetrahedron 2002, 58, 5957-5978. doi:10.1016/S0040-4020(02)00584-7

13. Felpin, F.-X.; Lebreton, J. Eur. J. Org. Chem. 2003, 3693-3712. doi:10.1002/ejoc.200300193

14. Bailey, P. D.; Millwood, P. A.; Smith, P. D. Chem. Commun. 1998, 633-640. doi:10.1039/a709071d

15. O'Hagan, D. Nat. Prod. Rep. 2000, 17, 435-446. doi:10.1039/a707613d

16. Buffat, M. G. P. Tetrahedron 2004, 60, 1701-1729. doi:10.1016/j.tet.2003.11.043

17. Weintraub, P. M.; Sabol, J. S.; Kane, J. M.; Borcherding, D. R. Tetrahedron 2003, 59, 2953-2989. doi:10.1016/S0040-4020(03)00295-3

18. Husson, H.-P.; Royer, J. Chem. Soc. Rev. 1999, 28, 383-394. doi:10.1039/a900153k

19. Escolano, C.; Amat, M.; Bosch, J. Chem.-Eur. J. 2006, 12, 8198-8207. doi:10.1002/chem.200600813

20. Comins, D. L.; Fulp, A. B. Tetrahedron Lett. 2001, 42, 6839-6841. doi:10.1016/S0040-4039(01)01432-0

21. Comins, D. L.; Brooks, C. A.; Ingalls, C. L. J. Org. Chem. 2001, 66, 2181-2182. doi:10.1021/jo001609|

22. Comins, D. L.; Libby, A. H.; Al-awar, R. S.; Foti, C. J. J. Org. Chem. 1999, 64, 2184-2185. doi:10.1021/jo990192k

23. Comins, D. L.; Kuethe, J. T.; Miller, T. M.; Février, F. C.; Brooks, C. A J. Org. Chem. 2005, 70, 5221-5234. doi:10.1021/jo050559n

24. Kuethe, J. T.; Comins, D. L. Org. Lett. 2000, 2, 855-857. doi:10.1021/ol0056271

25. Comins, D. L.; Zhang, Y.-m.; Joseph, S. P. Org. Lett. 1999, 1, 657-659. doi:10.1021/ol990738p

26. Dounay, A. B.; Overman, L. E.; Wrobleski, A. D. J. Am. Chem. Soc. 2005, 127, 10186-10187. doi:10.1021/ja0533895

27. Lin, N.-H.; Overman, L. E.; Rabinowitz, M. H.; Robinson, L. A.; Sharp, M. J.; Zablocki, J. J. Am. Chem. Soc. 1996, 118, 9062-9072. doi:10.1021/ja961641q

28. Castro, P.; Overman, L. E.; Zhang, X.; Mariano, P. S. Tetrahedron Lett. 1993, 34, 5243-5246. doi:10.1016/S0040-4039(00)73963-3

29. Hong, C. Y.; Kado, N.; Overman, L. E. J. Am. Chem. Soc. 1993, 115, 11028-11029. doi:10.1021/ja00076a086

30. Gedig, T.; Dettner, K.; Seifert, K. Tetrahedron 2007, 63, 2670-2674. doi:10.1016/j.tet.2007.01.024

31. Trost, B. M.; Cramer, N.; Bernsmann, H. J. Am. Chem. Soc. 2007, 129, 3086-3087. doi:10.1021/ja070142u

32. Islam, I.; Bryant, J.; May, K.; Mohan, R.; Yuan, S.; Kent, L.; Morser, J.; Zhao, L.; Vergona, R.; White, K.; Adler, M.; Whitlow, M.; Buckman, B. O. Bioorg. Med. Chem. Lett. 2007, 17, 1349-1354. doi:10.1016/j.bmcl.2006.11.078

33. Pandey, S. K.; Kumar, P. Tetrahedron Lett. 2005, 46, 4091-4093. doi:10.1016/j.tetlet.2005.04.013 
34. Takahata, H.; Saito, Y.; Ichinose, M. Org. Biomol. Chem. 2006, 4, 1587-1595. doi:10.1039/B601489E

35. Kim, S.-G.; Lee, S. H.; Park, T.-H. Tetrahedron Lett. 2007, 48, 5023-5026. doi:10.1016/j.tetlet.2007.05.100

36. Breuning, M.; Steiner, M. Synthesis 2006, 1386-1389. doi:10.1055/s-2006-926419

37. Itoh, T.; Nishimura, K.; Nagata, K.; Yokoya, M. Synlett 2006, 2207-2210. doi:10.1055/s-2006-948203

38. Gebauer, J.; Blechert, S. Synlett 2005, 2826-2828. doi:10.1055/s-2005-918942

39. Enders, D.; Thiebes, C. Pure Appl. Chem. 2001, 73, 573-578. doi:10.1351/pac200173030573

40. Davis, F. A.; Santhanaraman, M. J. Org. Chem. 2006, 71, 4222-4226. doi:10.1021/jo060371j

41. Ciblat, S.; Besse, P.; Papastergiou, V.; Veschambre, H.; Canet, J.-L.; Troin, Y. Tetrahedron: Asymmetry 2000, 11, 2221-2229. doi:10.1016/S0957-4166(00)00162-2

42. Jo, E.; Na, Y.; Chang, S. Tetrahedron Lett. 1999, 40, 5581-5582. doi:10.1016/S0040-4039(99)01081-3

43. Schaudt, M.; Blechert, S. J. Org. Chem. 2003, 68, 2913-2920. doi:10.1021/jo026803h

44. Nicolau, K. C.; Bulger, P. G.; Sarlah, D. Angew. Chem., Int. Ed. 2005, 44, 4490-4527. doi:10.1002/anie.200500369

45. Takahata, H.; Banba, Y.; Ouchi, H.; Nemoto, H.; Kato, A.; Adachi, I. J. Org. Chem. 2003, 68, 3603-3607. doi:10.1021/jo034137u

46. Kim, I. S.; Oh, J. S.; Zee, O. P.; Jung, Y. H. Tetrahedron 2007, 63, 2622-2633. doi:10.1016/j.tet.2007.01.028

47. Felpin, F.-X.; Girard, S.; Vo-Thanh, G.; Robins, R. J.; Villiéras, J.; Lebreton, J. J. Org. Chem. 2001, 66, 6305-6312. doi:10.1021/jo010386b

48. Mulzer, J.; Öhler, E. Top. Organomet. Chem. 2004, 13, 269-366. doi:10.1007/b98768

49. Kim, S.; Lee, Y. M.; Lee, J.; Lee, T.; Fu, Y.; Song, Y.; Cho, J.; Kim, D. J. Org. Chem. 2007, 72, 4886-4891. doi:10.1021/jo070668x

50. Goodenough, K. M.; Moran, W. J.; Raubo, P.; Harrity, J. P. A. J. Org. Chem. 2005, 70, 207-213. doi:10.1021/jo048455k

51. Gerasyuto, A. I.; Hsung, R. P. Org. Lett. 2006, 8, 4899-4902. doi:10.1021/ol0619359

52. Harrity, J. P. A.; Provoost, O. Org. Biomol. Chem. 2005, 3, 1349-1358. doi:10.1039/b502349c

53. Itoh, J.; Fuchibe, K.; Akiyama, T. Angew. Chem., Int. Ed. 2006, 45, 4796-4798. doi:10.1002/anie.200601345

54. Hynes, P. S.; Stranges, D.; Stupple, P. A.; Guarna, A.; Dixon, D. J. Org. Lett. 2007, 9, 2107-2110. doi:10.1021/ol070532l

55. Ye, J.; Dixon, D. J.; Hynes, P. S. Chem. Commun. 2005, 4481-4483. doi:10.1039/b508833j

56. Okino, T.; Hoashi, Y.; Takemoto, Y. J. Am. Chem. Soc. 2003, 125, 12672-12673. doi:10.1021/ja036972z

57. Li, H.; Wang, Y.; Tang, L.; Deng, L. J. Am. Chem. Soc. 2004, 126, 9906-9907. doi:10.1021/ja047281।

58. McCooey, S. H.; Connon, S. J. Angew. Chem., Int. Ed. 2005, 44, 6367-6370. doi:10.1002/anie.200501721

59. Connon, S. J. Chem. Commun. 2008, 2499-2510. doi:10.1039/b719249e

60. Hynes, P. S.; Stupple, P. A.; Dixon, D. J. Org. Lett. 2008, 10, 1389-1391. doi:10.1021/ol800108u

61. Jakubec, P.; Helliwell, M.; Dixon, D. J. Org. Lett. 2008, 10, 4267-4270. doi:10.1021/ol801666w

62. Jakubec, P.; Cockfield, D. M.; Dixon, D. J. J. Am. Chem. Soc. 2009, 131, 16632-16633. doi:10.1021/ja908399s
63. Kyle, A. F.; Jakubec, P.; Cockfield, D. M.; Cleator, E.; Skidmore, J.; Dixon, D. J. Chem. Commun. 2011, 47, 10037-10039. doi:10.1039/c1cc13665h

64. Jakubec, P.; Kyle, A. F.; Calleja, J.; Dixon, D. J. Tetrahedron Lett. 2011, 52, 6094-6097. doi:10.1016/j.tetlet.2011.09.016

65. Yu, M.; Wang, C.; Kyle, A. F.; Jakubec, P.; Dixon, D. J.; Schrock, R. R.; Hoveyda, A. H. Nature 2011, 479, 88-93. doi:10.1038/nature10563

66. Mühlstädt, M.; Schulze, B. J. Prakt. Chem. 1975, 317, 919-925. doi:10.1002/prac.19753170606

67. Bhagwatheeswaran, H.; Gaur, S. P.; Jain, P. C. Synthesis 1976, 615-616. doi:10.1055/s-1976-24142

68. Desai, M. C.; Thadeio, P. F.; Lefkowitz, S. L. Tetrahedron Lett. 1993, 34, 5831-5834. doi:10.1016/S0040-4039(00)73791-9

69. Desai, M. C.; Lefkowitz, S. L. Bioorg. Med. Chem. Lett. 1993, 3, 2083-2086. doi:10.1016/S0960-894X(01)81021-0

70. Nara, S.; Tanaka, R.; Eishima, J.; Hara, M.; Takahashi, Y.; Otaki, S.; Foglesong, R. J.; Hughes, P. F.; Turkington, S.; Kanda, Y. J. Med. Chem. 2003, 46, 2467-2473. doi:10.1021/jm020522k

71. Tanaka, R.; Rubio, A.; Harn, N. K.; Gernert, D.; Grese, T. A.; Eishima, J.; Hara, M.; Yoda, N.; Ohashi, R.; Kuwabara, T.; Soga, S.; Akinaga, S.; Nara, S.; Kanda, Y. Bioorg. Med. Chem. 2007, 15, 1363-1382. doi:10.1016/j.bmc.2006.11.007

72. Pei, Z.; Li, X.; von Geldern, T. W.; Longenecker, K.; Pireh, D.; Stewart, K. D.; Backes, B. J.; Lai, C.; Lubben, T. H.; Ballaron, S. J.; Beno, D. W. A.; Kempf-Grote, A. J.; Sham, H. L.; Trevillyan, J. M. J. Med. Chem. 2007, 50, 1983-1987. doi:10.1021/jm061436d

73. Xu, F.; Corley, E.; Zacuto, M.; Conlon, D. A.; Pipik, B.; Humphrey, G.; Murry, J.; Tschaen, D. J. Org. Chem. 2010, 75, 1343-1353. doi:10.1021/jo902573q

74. Xu, F.; Corley, E.; Murry, J. A.; Tschaen, D. M. Org. Lett. 2007, 9, 2669-2672. doi:10.1021/ol070909n

75. Pelletier, S. M.-C.; Ray, P. C.; Dixon, D. J. Org. Lett. 2009, 11, 4512-4515. doi:10.1021/ol901640v

76. Pelletier, S. M.-C.; Ray, P. C.; Dixon, D. J. Org. Lett. 2011, 13, 6406-6409. doi:10.1021/ol202710g

77. Barber, D. M.; Sanganee, H.; Dixon, D. J. Chem. Commun. 2011, 47 , 4379-4381. doi:10.1039/c1cc10751h

78. Rychnovsky, S. D.; Beauchamp, T.; Vaidyanathan, R.; Kwan, T. J. Org. Chem. 1998, 63, 6363-6374. doi:10.1021/jo9808831

79. Westermann, B. Angew. Chem., Int. Ed. 2003, 42, 151-153. doi:10.1002/anie.200390071

80. Kobayashi, S.; Mori, Y.; Fossey, J. S.; Salter, M. M. Chem. Rev. 2011, 111, 2626-2704. doi:10.1021/cr100204f

81. Humphrey, J. M.; Arnold, E. P.; Chappie, T. A.; Feltenberger, J. B.; Nagel, A.; Simon, W.; Suarez-Contreras, M.; Tom, N. J.; O'Neill, B. T. J. Org. Chem. 2009, 74, 4525-4536. doi:10.1021/jo9003184

82. Imashiro, R.; Uehara, H.; Barbas, C. F., III. Org. Lett. 2010, 12, 5250-5253. doi:10.1021/ol102292a

83. Wang, Y.; Yu, D.-F.; Liu, Y.-Z.; Wei, H.; Luo, Y.-C.; Dixon, D. J.; Xu, P.-F. Chem.-Eur. J. 2010, 16, 3922-3925. doi:10.1002/chem.201000059

84. Only one diastereomer was observed by ${ }^{1} \mathrm{H}$ NMR.

85. Elliot, M. C.; Williams, E. Org. Biomol. Chem. 2003, 1, 3038-3047. doi:10.1039/b306159k

86. Struve, C.; Christophersen, C. Heterocycles 2003, 60, 1907-1914. doi:10.3987/COM-03-9802

87. Scully, F. E., Jr. J. Org. Chem. 1980, 45, 1515-1517. doi:10.1021/jo01296a036 
88. Davis, B. G.; Maughan, M. A. T.; Chapman, T. M.; Villard, R.; Courtney, S. Org. Lett. 2002, 4, 103-106. doi:10.1021/ol016970o

89. Bertrand, M.; Poissonnet, G.; Théret-Bettiol, M.-H.; Gaspard, C.; Werner, G. H.; Pfeiffer, B.; Renard, P.; Léonce, S.; Dodd, R. H. Bioorg. Med. Chem. 2001, 9, 2155-2164.

doi:10.1016/S0968-0896(01)00119-5

90. Warrener, R. N.; Liu, L.; Russell, R. A. Tetrahedron 1998, 54, 7485-7496. doi:10.1016/S0040-4020(98)00378-0

91. Caroon, J. M.; Clark, R. D.; Kluge, A. F.; Lee, C. H.; Strosberg, A. M. J. Med. Chem. 1983, 26, 1426-1433. doi:10.1021/jm00364a013

92. Venkov, A. P.; Statkova-Abeghe, S. Synth. Commun. 1996, 26 , 127-134. doi:10.1080/00397919608003871

93. Grunewald, G. L.; Dahanukar, V. H.; Ching, P.; Criscione, K. R. J. Med. Chem. 1996, 39, 3539-3546. doi:10.1021/jm9508292

94. Meyers, A. I.; Hutchings, R. H. Tetrahedron 1993, 49, 1807-1820. doi:10.1016/S0040-4020(01)80537-8

95. García, E.; Lete, E.; Sotomayor, N. J. Org. Chem. 2006, 71, 6776-6784. doi:10.1021/jo060903w

96. Itoh, T.; Miyazaki, M.; Fukuoka, H.; Nagata, K.; Ohsawa, A. Org. Lett. 2006, 8, 1295-1297. doi:10.1021/ol0530326

97. Ma, J.; Yin, W.; Zhou, H.; Cook, J. M. Org. Lett. 2007, 9, 3491-3494. doi:10.1021/ol071220l

98. Sheludko, Y.; Gerasimenko, I.; Kolshorn, H.; Stöckigt, J. J. Nat. Prod. 2002, 65, 1006-1010. doi:10.1021/np0200919

99. Bailey, P. D.; Morgan, K. M. J. Chem. Soc., Perkin Trans. 12000 , 3578-3583. doi:10.1039/B005695M

100.Batista, C. V. F.; Schripsema, J.; Verpoorte, R.; Rech, S. B.; Henriques, A. T. Phytochemistry 1996, 41, 969-973. doi:10.1016/0031-9422(95)00666-4

101.Kuehne, M. E.; Muth, R. S. J. Org. Chem. 1991, 56, 2701-2712. doi:10.1021/jo00008a025

102. Martin, S. F.; Benage, B.; Hunter, J. E. J. Am. Chem. Soc. 1988, 110, 5925-5927. doi:10.1021/ja00225a068

103. The relative stereochemistry was confirmed by the measurement of $J$-coupling constants and unambiguously determined by single-crystal X-ray analysis.

104.Eliel, E. L.; Wilen, S. H.; Mander, L. N. Stereochemistry of Organic Compounds; John Wiley \& Sons: New York, 1994. See for the definition of crystallisation-induced transformations.

105. Yoshioka, R. Top. Curr. Chem. 2007, 269, 83-132. doi:10.1007/128_2006_094

106.Brands, K. M. J.; Davies, A. J. Chem. Rev. 2006, 106, 2711-2733. doi:10.1021/cr0406864

107.Anderson, N. G. Org. Process Res. Dev. 2005, 9, 800-813. doi:10.1021/op050119y

108.Ďuriš, A.; Wiesenganger, T.; Moravčíková, D.; Baran, P.; Kožíšek, J.; Daïch, A.; Berkeš, D. Org. Lett. 2011, 13, 1642-1645. doi:10.1021/ol2001057

109.Adams, H.; Anderson, J. C.; Peace, S.; Pennell, A. M. K. J. Org. Chem. 1998, 63, 9932-9934. doi:10.1021/jo981700d

110. The epimerisation studies were performed in $\mathrm{MeOH}(c 0.015 \mathrm{M})$ to ensure the full solubility of all reagents and products.

111. Absolute stereochemistry assigned by analogy with previous results of Michael addition to nitroolefin electrophiles catalyzed by $\mathbf{9}$; see reference [55]

112.Dixon, D. J.; Ley, S. V.; Rodríguez, F. Angew. Chem., Int. Ed. 2001, 40, 4763-4765. doi:10.1002/1521-3773(20011217)40:24<4763::AID-ANIE4763>3.0.C O;2-D

See for a related multicomponent reaction.
113. Ono, N.; Miyake, H.; Tamura, R.; Kaji, A. Tetrahedron Lett. 1981, 22, 1705-1708. doi:10.1016/S0040-4039(01)90417-4

See for seminal work.

114.Ono, N.; Kaji, A. Synthesis 1986, 693-704. doi:10.1055/s-1986-31754

115. Tormo, J.; Hays, D. S.; Fu, G. C. J. Org. Chem. 1998, 63, 5296-5297. doi:10.1021/jo980789k

116. Shen, B.; Johnston, J. N. Org. Lett. 2008, 10, 4397-4400. doi:10.1021/ol801797h

117. Meyers, A. I.; Downing, S. V.; Weiser, M. J. J. Org. Chem. 2001, 66, 1413-1419. doi:10.1021/jo001548r

118. Hirosawa, C.; Wakasa, N.; Fuchikami, T. Tetrahedron Lett. 1996, 37 , 6749-6752. doi:10.1016/S0040-4039(96)01458-X

\section{License and Terms}

This is an Open Access article under the terms of the Creative Commons Attribution License

(http://creativecommons.org/licenses/by/2.0), which permits unrestricted use, distribution, and reproduction in any medium, provided the original work is properly cited.

The license is subject to the Beilstein Journal of Organic Chemistry terms and conditions:

(http://www.beilstein-journals.org/bjoc)

The definitive version of this article is the electronic one which can be found at: doi:10.3762/bjoc. 8.64 